Volume 5, Issue S1 (2020), pp. 21-29 Journal of School Administration Research and Development ISSN: 2470-8496 Print/ ISSN: 2470-850X Online

ojed.org/jsard

\title{
Ensuring Co-teaching Continues Virtually: A School Leader's Imperative
}

\author{
Wendy W. Murawski \\ California State University, Northridge, USA
}

\section{ABSTRACT}

Moving to remote instruction can be daunting, but it is no reason to stop including students with disabilities. Co-teaching should be used as a service delivery model to support students in their least restrictive environment, which is often the general education classroom. School leaders need to continue to promote inclusive education, even during a pandemic.

Keywords: collaboration, collaborative teaching, co-teaching, inclusion, inclusive education

Teachers, administrators and families are scrambling as schools nationally move to on-line, digital, virtual, and hybrid instruction during the COVID-19 pandemic. While online instruction is certainly not new and some schools have provided electronic classrooms for years, the majority of students in the United States receive their instruction in brick and mortar schools. A total of 56.6 million students attended school in the United States in 2019 (NCES, 2019); prior to the pandemic, the National Education Policy Center (NEPC) reported that there were just over 500 virtual schools and 300 blended schools, serving a total of around 432,000 students (Molner et al., 2019). Clearly, the vast majority of students are used to physically attending school as opposed to logging in for their instruction. There are certainly numerous factors to consider when moving 
to an online or hybrid environment, but a major one is the instruction of students with disabilities and other special needs. Even in the best of times and in a stable context, teachers struggle to differentiate and include all learners in their least restrictive environment (McCoy \& Mathur, 2017).

Students who have been found eligible for special education services are legally entitled to receive instruction in their least restrictive environment (LRE) as per the Individuals with Disabilities Education Act (IDEA, 2004). For most, that LRE is considered the general education classroom. Many of these students have been successful with the ongoing presence and support of a special education teacher or paraprofessional in the classroom with them. This does not need to change simply due to a move to an online format. In fact, legally, school leaders could face due process issues if they unilaterally change the way in which a student is receiving his or her services (Dalton, in press). The United States Department of Education (USDOE) has issued guidance to traditional schools as they transition to online instruction during the recent pandemic; Rodriguez and Murawski (in press) note that "the basic presumption that 'a student with an identified disability is a general education student first' guides the advice provided by the USDOE" (p. 515). Thus, if a student who has an identified disability is now required to receive all supports through breakout rooms with a special educator, essentially returning that student to a more segregated setting merely because it is easier for the teachers, that is setting the stage for a lawsuit, not to mention raising serious social justice questions.

Many schools have turned to co-teaching as a way in which a special educator and general education teacher might collaborate to address student needs (Scruggs \& Mastopieri, 2017). Merely putting two individuals together most certainly does not solve the problem; however, these individuals require training, administrative support, co-planning time, and more (Murawski \& Bernhardt, 2016). When administrators face the issue of trying to continue coteaching in a virtual or "remote" world, it is likely many will feel that this is a hurdle to be faced in the future and will opt instead to go back to the status quo of allowing students who have Individualized Education Plans (IEPs) and other needs to be pulled out for their supports. It is imperative that this backslide not be allowed to occur.

\section{MAIN ARGUMENT/LITERATURE}

Ensuring that students with disabilities have access to an inclusive school environment, to include classes, social events, extracurricular activities and the like, that will allow them to make progress is not only a legal requirement (see 
Endrew v. Douglas, 2017 \& IDEA, 2004) but, arguably more importantly, a social justice issue. School administrators have increasingly recognized the need to meaningfully include students with disabilities, English language learners, students with 504 plans, and those who are homeless or food insecure. These strides match our society's increasing recognition of the true diversity of our community: in gender, race, ethnicity, sexual preference, learning abilities, and so on. As the field of neurodiversity grows and teachers become more aware of how all students learn, they can create lessons and assignments that are more universally designed and allow for the various neurodevelopmental profiles of their students (Armstrong, 2017).

Doing so, however, requires a culture that respects diversity, encourages collaboration, and allows for differentiation. Administrators need to set the tone that classes-albeit remote or face-to-face-need to continue to recognize and address learner differences. Those teachers who merely sit in front of a camera and lecture to a large class of students, asking students to have their video and audio turned off so as to minimize distractions for the teacher, need to receive professional development on how to provide engaging online instruction. In fact, Karten and Murawski (2020) provide concrete examples of the "do's, don'ts, and do betters" for applying co-teaching to the remote environment. Figure 1 provides a Frayer model of virtual co-teaching from their recent book. The various co-teaching models were first identified by Bauwens et al. (1989) and later made popular by Lynne Cook and Marilyn Friend; an application of those five models to remote learning is provided in Table 1. Since research has found that collaboration in the form of co-teaching in the classroom results in increased cognitive engagement of students (Lochner, et al., 2019), more interactive and universally designed lessons for students (Murawski \& Ricci, 2019), and more creative planning (Pratt, et al., 2017), remote co-teaching is likely to yield similar benefits. 


\section{Figure 1}

\section{Frayer Model of Virtual Co-Teaching}

\section{Definition}

Two teachers, often a GE and SE teacher, work collaboratively to increase the knowledge and skills of students with and without exceptionalities within a digital environment. The same co-teaching principles to offer parity, monitor learner progress, be respectful, and invite input from students, families, and related providers are valued in the virtual setting.

\section{Characteristics}

Co-teachers share roles and responsibilities for content and students with planning, instruction, and assessment. Ongoing communications happen both synchronously and ascynchronously among teachers, related staff, students, and families to ensure that the specially designed instruction is appropriately delivered within the digital environment.

\section{Virtual Co-Teaching}

\section{Examples}

Co-teachers teach parallel, station or alternate lessons to small groups of learners in online breakrooms. They use Zoom, WebEx, Schoology, and Google Meets as online platforms. Coteachers split the screen during an online lesson so students see both teachers' faces. They offer opportunities for practice, repetition, and enrichment.

\section{Nonexamples}

One co-teacher leads the lesson while the other co-teacher cooks dinner for his or her family. Co-teachers do not plan, instruct, or reflect on virtual lessons together. Professional development is halted. One co-teacher is the sole voice heard as the other teacher hangs back and waits for instructions. Students are always in large group together.

Note. From Karten, T. \& Murawski, W. W. (2020). Co-teaching Do's, Don'ts, and Do Betters (p.55). C 2020 ASCD. REPRODUCED WITH PERMISSION. ALL RIGHTS RESERVED. 


\section{Table 1}

Co-teaching Models Applied to Remote Instruction

Co-teaching model Description Application in remote environment

\begin{tabular}{|c|c|c|}
\hline $\begin{array}{l}\text { One Teach-One } \\
\text { Support (includes } \\
\text { One Teach-One } \\
\text { Assist and One } \\
\text { Teach-One }\end{array}$ & $\begin{array}{l}\text { One educator leads direct } \\
\text { instruction while the other } \\
\text { supports students, collects } \\
\text { data, asks questions, sets } \\
\text { up lab activities, and more. }\end{array}$ & $\begin{array}{l}\text { As one provides instruction, the } \\
\text { other takes attendance online, chats } \\
\text { with students in chatbox, monitors } \\
\text { engagement, and sets up online } \\
\text { polls. }\end{array}$ \\
\hline
\end{tabular}

Team Teaching Both teachers share the stage: discussing, roleplaying, modeling, debating, running games and activities, and so on.

Parallel Teaching Both teachers take half the class to teach the same content in the same way, the same content in a different way, or different content.

\begin{tabular}{|c|c|}
\hline Station Teaching & $\begin{array}{l}\text { Students are broken into } \\
\text { three or more groups that } \\
\text { rotate, getting different } \\
\text { instruction in each station. } \\
\text { Co-teachers can monitor, } \\
\text { facilitate, and teach } \\
\text { various stations. }\end{array}$ \\
\hline
\end{tabular}

Alternative Teaching
One co-teacher instructs the large group, while the other works with a small group on re-teaching, preteaching, or enrichment work.
Co-teachers provide varying opinions of a literary analysis, model appropriate ways to interact in online breakout rooms, and share their screens to explain steps in the upcoming writing project.

Co-teachers put students in two break-out rooms and introduce math content in different ways: one shows a Khan Academy video while the other has students use information from their own rooms to create an equation.

Three groups are created to go through four stations. Each coteacher takes a station to lead, one station is for a "brain break," and the fourth station is for groupwork using a provided website and resources.

As the majority of the class completes some independent practice and one co-teacher monitors their work, the other moves a small group to a breakout room to answer questions and provide review prior to them moving to independent practice. 
To address the diversity of our classes, co-teaching, wherein a special education teacher or specialist partners with a general education classroom teacher to co-plan, co-instruct, and co-assess a diverse group of students in the same class environment (Murawski \& Ricci, 2019), needs to continue. Certainly, some teachers will struggle with online instruction more than others, however many of the same strategies used in onsite collaboration can continue during online instruction. Table 2 provides an article, blog, and video all designed to help educators adapt from the in-person classroom to the virtual one. As more schools move to online instruction both during and after the pandemic, the literature in this area will grow. Educators need to be prepared to continue to collaborate around all students' needs, including those who have disabilities, and school leaders need to recognize the imperative to help them do so.

Table 2

Online Resources Related to Virtual Co-teaching

Organization

Link

ASCD

https://inservice.ascd.org/strategies-for-co-teaching-from-your-couch/

Understood

https://www.understood.org/en/school-learning/for-

educators/universal-design-for-learning/co-teaching-during-distance-

learning-tips-for-partnering-virtually

2 TEACH

https://www.youtube.com/watch?v=roLQd7AI3-s\&feature=youtu.be

\section{CONCLUSIONS/ IMPLICATIONS}

Though many students will struggle working virtually, it is safe to say that students with significant support needs will face even more challenges than their peers ( 2 Teach, 2020). Asking teachers to not only figure out how to teach online and how to engage their typical learners virtually, but also to consider how to differentiate and accommodate within this environment, is asking a lot. Instead, rather than allowing their teachers to default back to the "this is my classroom" solo-taught situation, it is strongly recommended that school leaders emphasize the need for ongoing collaboration between teachers. Administrators should remind co-teaching faculty to divide and conquer to plan lessons, find resources, regroup students for smaller student-teacher ratios in online breakout rooms, and identify areas wherein students are struggling (Hodnett, 2020; Karten \& Murawski, 2020). 
Many educators may have been working through the barriers involved in inclusive education and co-teaching. Thus, it is completely understandable that, now facing the additional barrier of working virtually, these same educators may choose to abandon their attempts to embrace inclusive education. Despite a desire to do what is not only considered "right" but "best practice," they may be overwhelmed and prefer to default to what is more comfortable to them. Administrators and other school leaders may, in an effort to support their faculty during a challenging time, allow this to occur. If this happens, it will impair much of the work that has been done in schools to increase the inclusion of all students. It will allow teachers to feel that, depending on the situation, it is acceptable to return these students to pull-out type educational settings. It will chip away at the relationships that were beginning to form between general and special educators.

Co-teaching, both in face-to-face and remote environments, must continue. Teachers must be provided with support and professional development to build their collaborative relationships and share their diverse frames of reference and expertise. School leaders must continue to embrace and support inclusive education, considering the long-term ramifications, as their schools figure out how to move to online learning. Rather than putting inclusion and coteaching on a back burner or on hold, leaders must communicate to their faculty, parents and community that meeting the needs of all students continues to be an imperative, regardless of the platform of instruction.

\section{REFERENCES}

2 Teach (2020). Co-teaching in a virtual environment (Webinar featuring Dr. Wendy Murawski). YouTube. https://youtu.be/roLQd7AI3-s

Armstrong, T. (2017). Neurodiversity: The future of special education? Educational Leadership, 74(7), 10-16.

Bauwens, J., Hourcade, J. J., \& Friend, M. (1989). Cooperative teaching: A model for general and special education integration. Remedial \& Special Education, 10(2), 17-22. https://doi.org/10.1080/1045988X.1993.9944611

Dalton, M. A. (in press). Procedural safeguards and remedies for students with disabilities and their families. In J. A. Rodriguez and W. W. Murawski (Eds.). Special education law and policy: From foundation to application. Plural Publishing.

Endrew F. v Douglas County School District, 798 F.3d 1329 (10 ${ }^{\text {th }}$ Cir. 2015), 137 S. Ct. 988 (2017), 290 F. Supp. 3d 1175 (D. Colo. 2018). 
Hodnett, B.R. (2020). Co-teaching during distance learning: Tips for partnering virtually. Understood.org. https:/www.understood.org/en/schoollearning/for-educators/universal-design-for-learning/co-teaching-duringdistance-learning-tips-for-partnering-virtually

Individuals with Disabilities Education Act (IDEA), 20 U.S.C. $§ 1401$ et seq. (2004).

Karten, T. \& Murawski, W. W. (2020). Co-teaching do's don'ts, and do betters. ASCD.

Lochner, W.W., Murawski, W.W., \& True-Daley, J. (2019). The effect of coteaching on student cognitive engagement. Theory and Practice in Rural Education, 9(2), 6-19. https://doi.org/10.3776/tpre.2019.v9n2p6-19

McCoy, K. M., \& Mathur, S. R. (2017). Differentiation in the digital-based classroom: A Universal Design approach for inclusive settings in middle schools. Journal of Education and Development, 1(1), 1-11. https://doi.org/10.20849/jed.v1i1.219

Molnar, A., Miron, G., Elgeberi, N., Barbour, M.K., Huerta, L., Shafer, S.R., \& Rice, J. K. (2019). Virtual schools in the U.S. 2019. National Education Policy Center. http://nepc.colorado.edu/publication/virtual-schoolsannual-2019.

Murawski, W.W., \& Bernhardt, P. (2016). An administrator's guide to coteaching. Educational Leadership, 73(4), 30-34.

Murawski, W. W., \& Ricci, L. A. (2019). UDL and co-teaching: Establishing the perfect union (pp.141-155). In W. W. Murawski and K. L. Scott (Eds). What really works with Universal Design for Learning. Corwin. ISBN13: $978-1544338675$

National Center for Education Statistics (2019). Fast facts: Back to school statistics. https://nces.ed.gov/fastfacts/display.asp?id $=372$

Pratt, S.M., Imbody, S. M., Wolf, L.D., \& Patterson, A. L. (2017). Co-planning in co-teaching: A practical solution. Intervention in School and Clinic, 52(4), 243-249. https://doi.org/10.1177/1053451216659474

Rodriguez, J. A., \& Murawski, W. W. (in press). Special Education law and policy: From foundation to application. Plural Publishing.

Scruggs, T.E. \& Mastropieri, M.A. (2017). Making inclusion work with coteaching. Teaching Exceptional Children, 49(4), 284-293. https://doi.org/10.1177/0040059916685065 
WENDY W. MURAWSKI, Ph.D., is the Executive Director and Eisner Endowed Chair for the Center for Teaching and Learning at California State University Northridge. A professor of Special Education and international keynote speaker, Dr. Murawski has authored 14 books related to co-teaching and inclusive education.

Manuscript submitted: July 13, 2020

Manuscript revised: September 21, 2020 Accepted for publication: September 23, 2020 